\title{
Wpływ przebiegu lokomotywy na zmiany poziomu drgań jej wybranych zespołów
}

\begin{abstract}
W artykule przedstawiono analizę możliwości wykorzystania nadzoru monitorowania drgań zespołów lokomotywy do bieżacej oceny ich stanu technicznego. Wskazano na zastosowanie modelu do prognozowania jako narzędzia do szacowania dalszej poprawnej pracy zespolu lokomotywy.
\end{abstract}

\section{Wprowadzenie}

Podczas procesu eksploatacji każda maszyna podlega procesowi zużywania i degradacji, tracąc swoje cechy i własności nadane na etapie wytwarzania. Utrata cech prowadzi do pogorszenia charakterystyk eksploatacyjnych maszyny, jak i całego sytemu, którego jest elementem. Dlatego istotne jest w praktyce eksploatacyjnej śledzenie stanu technicznego maszyn, aby zminimalizować koszty eksploatacji wynikające $\mathrm{z}$ nadmiernego pogorszenia stanu maszyny lub $\mathrm{w}$ pore zapobiec jej uszkodzeniu.

$\mathrm{W}$ artykule przedstawiono wyniki badań poziomu drgań wybranych zespołów lokomotyw. Celem badań było przeanalizowanie zmian poziomu drgań zespołów w funkcji przebiegu lokomotywy pod kątem możliwości oceny ich stanu oraz budowy modeli pozwalających szacować stan wyeksploatowania zespołów lokomotywy. Badania zrealizowano na zespołach lokomotyw serii SM 42 będących w różnych stanach wyeksploatowania.

Stan techniczny badanych zespołów nie był znany, dlatego przyjęto założenie, że miarą odzwierciedlającą ich stan (zaawansowania procesów zużycia) będzie przebieg lokomotywy. Takie założenie pozwala na budowę modeli (krzywych stanu technicznego zespołów) w kategoriach przebiegu oraz ich predykcję. Opracowane modele mogą być wykorzystane do szacowania przebiegu do osiagnięcia granicznego poziomu drgań zespołu. W tym celu, dla każdego zespołu wyznaczono graniczny poziom drgań.

\section{Sposoby zużywania się maszyn}

Proces zużywania się lub degradacji własności użytkowych maszyn nie jest w swej strukturze zjawiskowej jednorodny, do celów diagnostyki można go podzielić na cztery fizykalnie różne procesy:

- zużycie zmęczeniowe,

- zużycie tarciowe,

- zużywanie przez pełzanie,

- zużywanie przez erozję.
Zużycie zmęczeniowe, występuje w trzech następujących formach [2]:

- objętościowej, prowadzącej do utraty spoistości materiału,

- powierzchniowej podczas ruchu - powodującej pitting (łuszczenie),

- powierzchniowej w złączach nieruchomych powodującej fretting (korozja cierna).

Każdorazowo czynnikiem sterującym są drgania, mające prosty związek z naprężeniami dynamicznymi, które opisuje zależność:

$$
\sigma=\rho c v k_{d}
$$

gdzie:

$$
\begin{aligned}
& \rho-\text { gęstość materiału, } \\
& c-\text { prędkość dźwięku, } \\
& v-\text { prędkość drgań, } \\
& k_{d}-1 \div 3 \text { współczynnik dynamiczny zależny od } \\
& \quad \text { postaci drgań. }
\end{aligned}
$$

Kolejna forma degradacji to zużycie tarciowe $\mathrm{w}$ parach kinematycznych maszyn, zależne od prędkości ruchu względnego oraz od nacisku jednostkowego, czyli również drgań, jeśli chodzi o jego składową dynamiczna. We wszystkich formach prowadzi ono do ubytków masowych, konsekwencją czego są luzy w parach kinematycznych [2].

Własności reologiczne materiału są przyczyną trzeciego sposobu zużywania przez pełzanie (płynięcie) co prowadzi do zmiany wymiarów i kształtów elementów maszyn. Intensywność tego zjawiska zależy od temperatury materiału, a także naprężenia co w składowej dynamicznej zawiera znów drgania.

Nie mniej ważne jest erozyjne zużywanie się elementów maszynowych i konstrukcji, polegające na fizycznej (kawitacja) lub chemicznej (korozja) degradacji i ubytku masowym materiału [2]. 


\section{Obiekt badań}

Obiektem, na którym dokonano badań zespołów była 4-osiowa lokomotywa manewrowa serii SM42 z przekładnią elektryczna, o mocy $800 \mathrm{KM}$. Na rysunku 1 przedstawiono rozmieszczenie zespołów w lokomotywie. Badania przeprowadzono na 10 lokomotywach pracujących bez obciążenia, z różnymi przebiegami, które przedstawiono $\mathrm{w}$ tabeli 1.

Pomiary drgań przeprowadzono dla każdej lokomotywy na następujących zespołach (maszynach) lokomotywy:

- silnik spalinowy,

- prądnica główna,

- wzbudnica,

- sprężarka powietrza,

- wentylator silników trakcyjnych.

Tabela 1. Zestawienie badanych lokomotyw i ich przebiegów

\begin{tabular}{|c|r|r|}
\hline Lp. & $\begin{array}{c}\text { Nr } \\
\text { lokomotywy }\end{array}$ & $\begin{array}{c}\text { Przebieg } \\
{[\mathbf{k m ]}]}\end{array}$ \\
\hline 1 & 613 & 272 \\
\hline 2 & 1101 & 764 \\
\hline 3 & 614 & 1454 \\
\hline 4 & 447 & 8690 \\
\hline 5 & 110 & 19562 \\
\hline 6 & 1105 & 27419 \\
\hline 7 & 650 & 50086 \\
\hline 8 & 1072 & 51880 \\
\hline 9 & 423 & 56815 \\
\hline 10 & 28 & 85755 \\
\hline
\end{tabular}

Mierzonymi parametrami drganiowymi były: skuteczna wartość przyspieszeń oraz prędkości drgań.

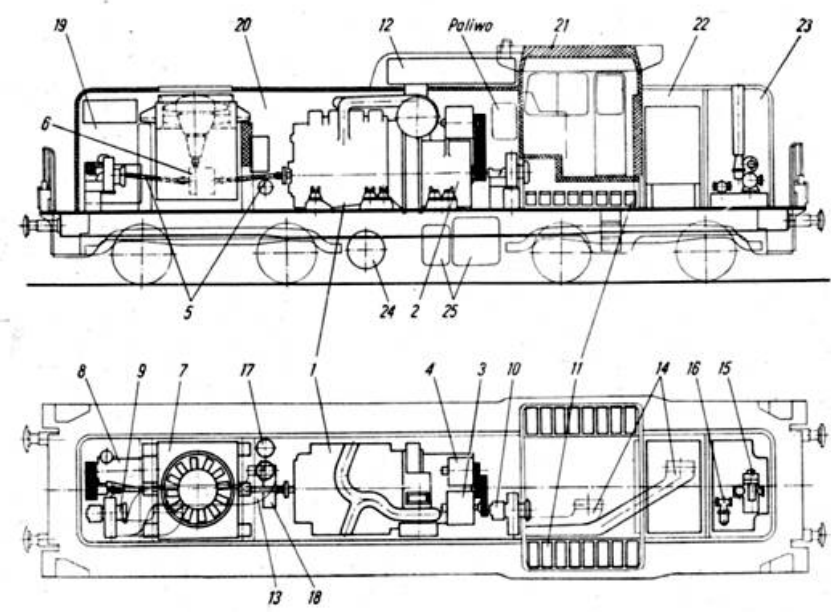

Rys. 1 Rozmieszczenie maszyn i urządzeń lokomotyw SM42 [1]

1-silnik spalinowy, 2-prqdnica główna, 3-prqdnica pomocnicza, 4wzbudnica, 5-waty pędne, 6-przekładnia $i$ sprzęgło, 7 zespółchłodzqcy $z$ wentylatorem, 8-sprężarka powietrza, 9,10wentylatory silników trakcyjnych, 11-bateria akumulatorów, 12thumik układu wydechu, 13,14-kanaty wentylacyjne elektrycznych silników trakcyjnych, 15-podgrzewacz wody, 16-pompa wody podgrzewacza, 17-filtry oleju, 18-wymiennik ciepla, 19-przedziat hamulcowy, 20-przedziat silnikowy, 21-izolacja akustyczna, 22przedziat elektryczny, 23-przedziat kotłowy, 24-zbiornik powietrza, 25-zbiornik paliwa.

\section{Punkty pomiarowe}

Poniżej zostały przedstawione wybrane punkty pomiarowe, a także ich rozmieszczenie na danym zespole lokomotywy spalinowej serii SM42, dla których przeprowadzono pomiary drgań. Punkty te zostały wybrane na podstawie możliwości dostępu do poszczególnych zespołów na pracującej lokomotywie oraz według podstawowej zasady wyboru punktów pomiarowych, że przetworniki pomiaru drgań powinny być zamocowane możliwie blisko źródeł generowania drgań lub ich propagacji. Takimi miejscami w przypadku mierzonych zespołów były: obudowy łożysk, mocowania do podstawy (posadowienia), miejsca pracy mechanizmów (uderzenia) czy też źródła zjawisk falowych.

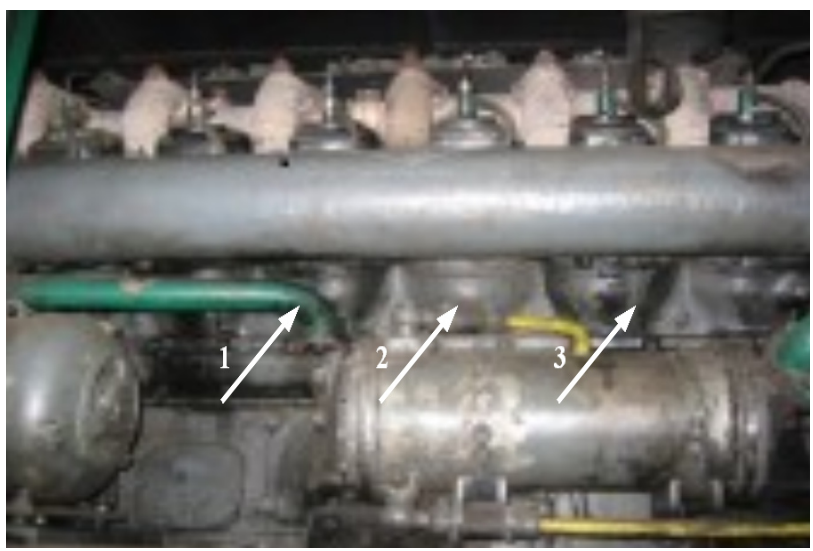

Rys. 2. Punkty pomiarowe silnika spalinowego

$\mathrm{Na}$ silniku spalinowym wszystkie trzy punkty zostały umieszczone na głowicy, przy wtryskiwaczach paliwa. $Z$ uwagi na to, że jest to miejsce, na wysokości którego zachodzą główne procesy silnikowe, istnieje zatem możliwość ich oceny przy takim usytuowaniu punktów pomiarowych.

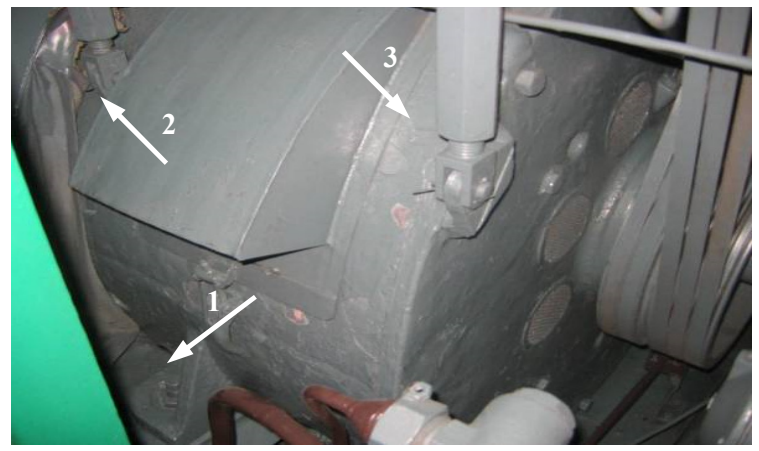

Rys. 3. Punkty pomiarowe prądnicy głównej [5]

$\mathrm{Na}$ pradnicy głównej wybrano trzy punkty pomiarowe:

1 - mocowanie prądnicy dolne,

2 - mocowanie prądnicy górne,

3 - obudowa łopatek wentylatora.

$\mathrm{Z}$ uwagi na brak możliwości umieszczenia punktów pomiarowych w miejscach ułożyskowania prądnicy głównej, wybrano te trzy w/w, charakterystyczne punkty pomiarowe. 


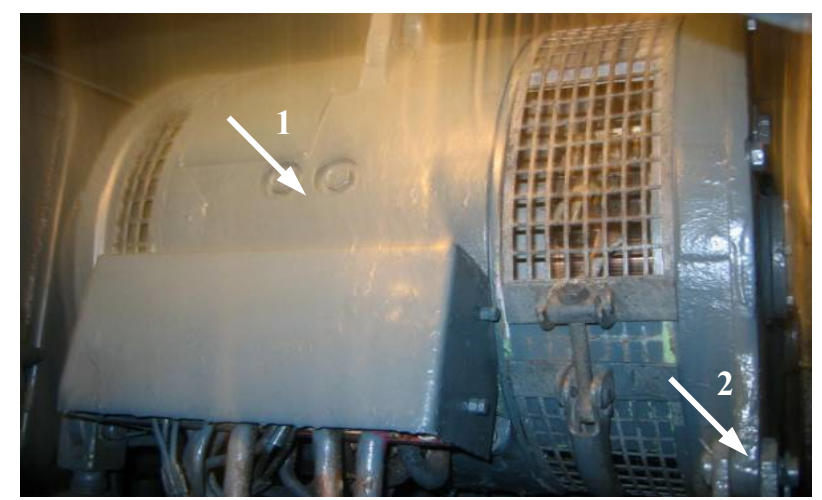

Rys. 4. Punkty pomiarowe wzbudnicy [5]

Ze względu na ograniczony dostęp, na wzbudnicy wybrano dwa punkty pomiarowe:

1 - obudowa wzbudnicy,

2 - mocowanie wzbudnicy.

Tak zlokalizowane punkty pomiarowe pozwolą na ogólna ocenę stanu wzbudnicy.

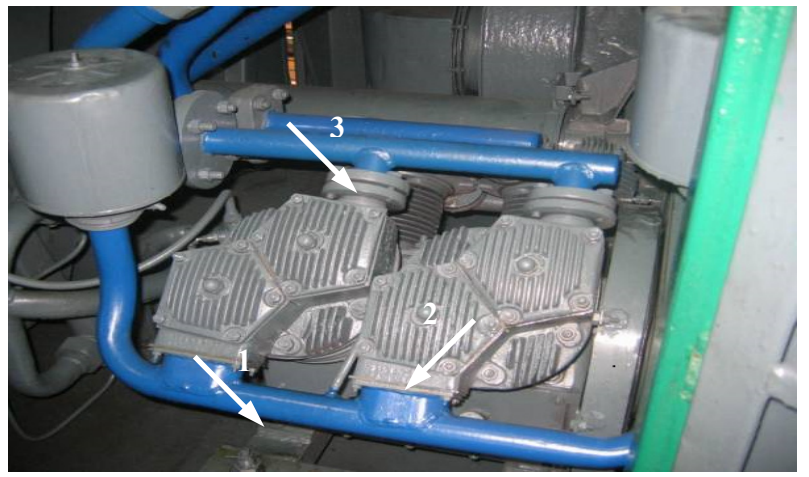

Rys. 5. Punkty pomiarowe sprężarki powietrza [5]

$\mathrm{Na}$ sprężarce powietrza wybrano 3 punkty pomiarowe:

1 - mocowanie sprężarki,

2 - głowica cylindra I stopnia sprężania,

3 - głowica cylindra II stopnia sprężania.

Wybrane punkty pomiarowe pozwolą na ocenę stanu zespołu tłokowo-cylindrowego oraz ogólnego poziomu drgań sprężarki.

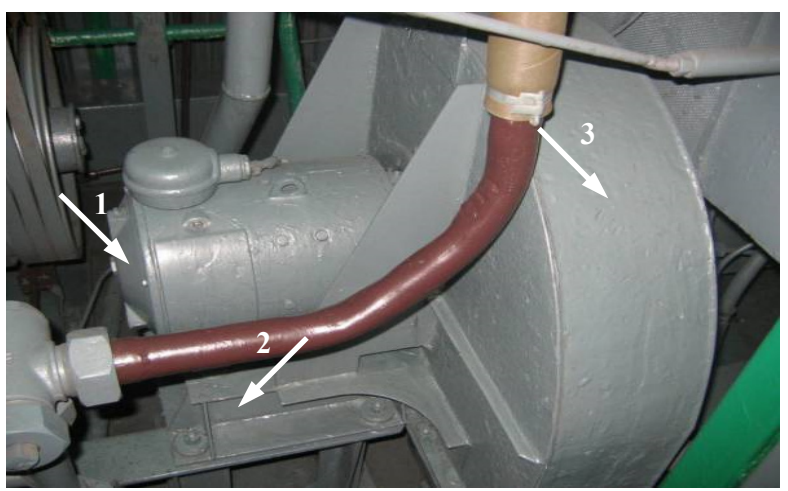

Rys. 6. Punkty pomiarowe wentylatora silników trakcyjnych [5]
$\mathrm{Na}$ wentylatorze silników trakcyjnych wybrano następujące punkty pomiarowe:

1 - obudowa łożyska silnika elektrycznego,

2 - mocowanie wentylatora,

3 - obudowa łopatek wentylatora.

Punkty pomiarowe 2 i 3 pozwolą na ocenę ogólnego poziomu drgań wentylatora, natomiast punkt pomiarowy 1 pozwoli na ocenę stanu silnika elektrycznego napędzającego wentylator silników trakcyjnych.

\section{Analiza wyników badań}

Analiza wyników badań, polegała na oszacowaniu dla każdego mierzonego parametru wartości granicznej z uzyskanych wyników pomiarów. Wartość ta została wyznaczona metodą opracowaną przez $\mathrm{C}$. Cempla, która polega na minimalizacji prawdopodobieństwa nie wykrycia awarii przy założonym poziomie zbędnych napraw $[2,3]$.

Wartość graniczną symptomu diagnostycznego w tej metodzie wyznacza się z zależności:

$$
S_{g} \leq \bar{S}+\sigma_{s} \sqrt{\frac{P(z)}{2 \cdot A}}
$$

gdzie:

$S_{g}$ - szukana wartość graniczna symptomu, $\bar{S}=\frac{1}{N} \sum_{i=1}^{n} S_{i}-$ wartość średnia symptomu w obserwowanej grupie maszyn $(\mathrm{Mz}) \mathrm{z}$ liczbą $\mathrm{N}$ obserwacji maszyn $\mathrm{W}$ różnych stanach eksploatacyjnych,

$\sigma_{s}=\sqrt{\frac{1}{N} \sum_{i=1}^{n}\left(S_{i}-\bar{S}\right)^{2}}-$ odchylenie standardowe obserwacji,

$P(z)=M_{z} / M$ - ocena prawdopodobieństwa zdatności (gotowości) obserwowanej grupy maszyn,

$A$ - dopuszczalne, w danym zakładzie, prawdopodobieństwo zbędnych remontów (błędnych decyzji diagnostycznych), $0<\mathrm{A}$ $<<1$.

Jak wynika z powyższego wzoru, wartość graniczna $S_{g}$ wynika $z$ własności obserwowanej grupy maszyn, zależy ona od ich ogólnego stanu i jakości remontów $\left(\mathrm{S}, \sigma_{\mathrm{s}}, \mathrm{P}(\mathrm{z})\right.$ ) oraz od założonego poziomu zbędnych napraw $-\mathrm{A}<<1[2,3]$.

W wyniku przeprowadzonych obliczeń wyników pomiarów metodą najmniejszych kwadratów z wykorzystaniem arkusza kalkulacyjnego Excel, otrzymano modele opisujące poziomy drgań w funkcji przebiegu lokomotywy. Dla każdego modelu, dla którego współczynnik determinacji $\mathrm{R}^{2}$ jest największy, dokonano prognozy parametru. 
Wyznaczone modele umożliwiają szacowanie poziomu drgań badanych zespołów lokomotywy w zależności od przebiegu lokomotywy. Mając jednocześnie oszacowaną wartość graniczną, można prognozować przebieg lokomotywy do osiagnięcia przez badany zespół granicznego poziomu drgań.

$\mathrm{Na}$ rysunkach 7 do 11 przedstawiono wybrane wyniki z analizy danych otrzymanych z pomiarów drgań zespołów lokomotywy.

$\mathrm{Na}$ rysunku 7 przedstawiono zmiany skutecznej wartości przyspieszeń drgań (RMS) w pierwszym punkcie pomiarowym na silniku (rys. 2) w funkcji przebiegu lokomotywy. Najbardziej korzystnym modelem okazał się model logarytmiczny. W oparciu o ten model przeprowadzono prognozę parametru do osiagnięcia wyznaczonej dla silnika wartości granicznej. Można zauważyć, że po przebiegu 50 tys. kilometrów poziom drgań silnika jest bliski wartości granicznej.

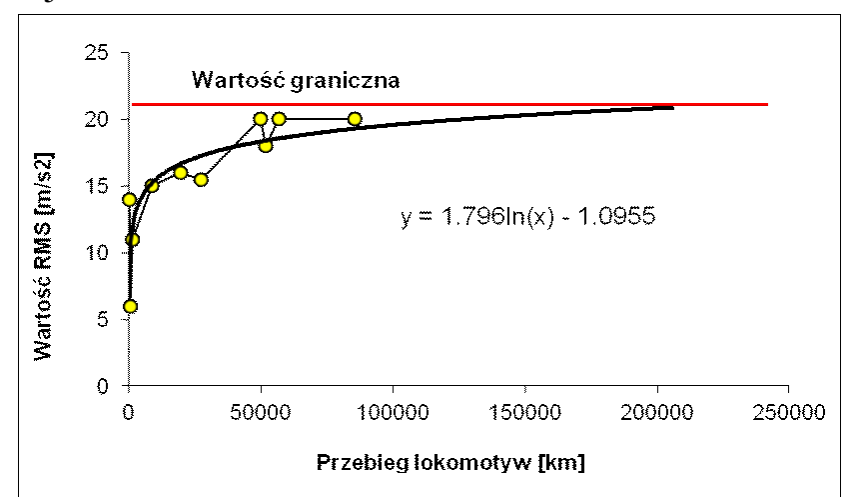

Rys. 7. Przebieg skutecznej wartości przyspieszenia drgań silnika spalinowego dla punktu pomiarowego $1 \mathrm{w}$ funkcji przebiegu lokomotywy

Na rysunku 8 przedstawiono zmiany skutecznej wartości przyspieszeń drgań (RMS) w pierwszym punkcie pomiarowym na prądnicy głównej (rys. 3) w funkcji przebiegu lokomotywy. Najlepszym modelem okazał się model potęgowy. W oparciu o ten model przeprowadzono prognozę parametru do osiagnięcia wyznaczonej dla prądnicy głównej wartości granicznej. Jak widać, prognoza wykazuje dłuższy przebieg do osiagnięcia wartości granicznej niż w przypadku silnika spalinowego.

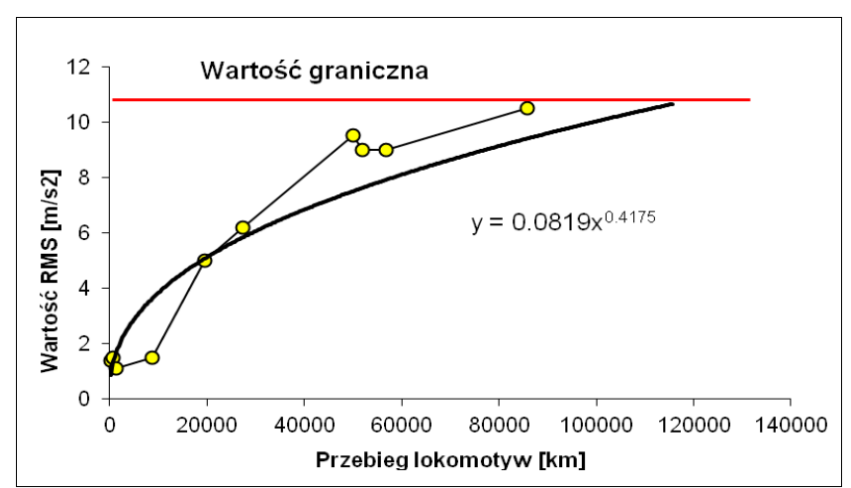

Rys. 8. Przebieg skutecznej wartości przyspieszenia drgań prądnicy głównej dla punktu pomiarowego $1 \mathrm{w}$ funkcji przebiegu lokomotywy
Rysunek 9 przedstawia zmiany skutecznej wartości przyspieszeń drgań (RMS) w drugim punkcie pomiarowym na wzbudnicy (rys. 4) w funkcji przebiegu lokomotywy. Najlepszym modelem okazał się model wykładniczy. W oparciu o ten model przeprowadzono prognoze parametru do osiagnięcia wyznaczonej dla wzbudnicy wartości granicznej. Można zauważyć, że model bardzo dobrze opisuje zmiany poziomu drgań wzbudnicy w funkcji przebiegu, a zatem można przyjąć, że prognoza ta dla wzbudnicy jest wiarygodna.

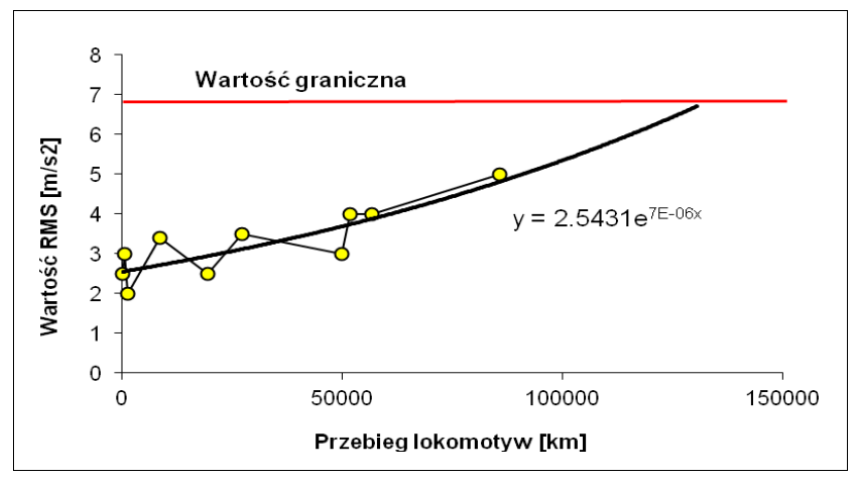

Rys. 9. Przebieg skutecznej wartości przyspieszenia drgań wzbudnicy dla punktu pomiarowego $2 \mathrm{w}$ funkcji przebiegu lokomotywy

Na rysunku 10 przedstawiono zmiany skutecznej wartości przyspieszeń drgań (RMS) w pierwszym punkcie pomiarowym na sprężarce powietrza (rys. 5) w funkcji przebiegu lokomotywy. Najlepszym modelem okazał się model potęgowy, który bardzo dobrze opisuje zmiany poziomu drgań sprężarki w funkcji przebiegu. $\mathrm{W}$ oparciu o ten model przeprowadzono prognoze parametru do osiagnięcia wyznaczonej dla wzbudnicy wartości granicznej.

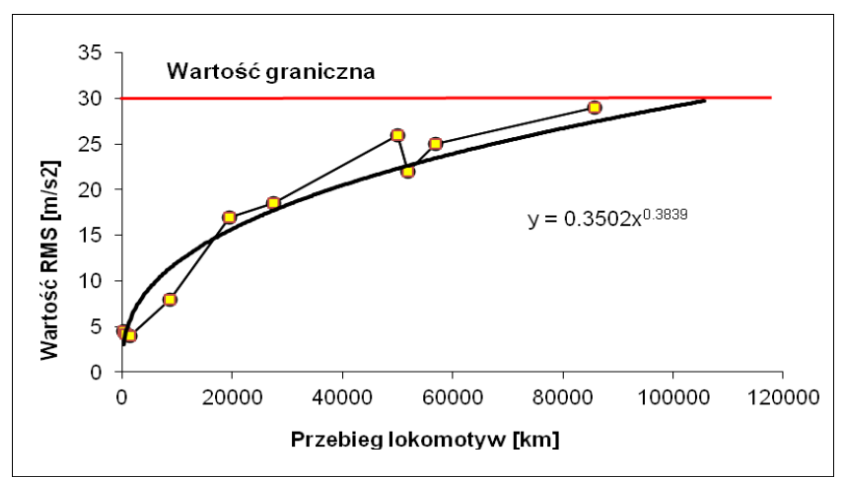

Rys. 10. Przebieg skutecznej wartości przyspieszenia drgań sprężarki powietrza $\mathrm{w}$ punkcie pomiarowym $1 \mathrm{w}$ funkcji przebiegu lokomotywy

$\mathrm{Na}$ rysunku 11 przedstawiono zmiany skutecznej wartości przyspieszeń drgań (RMS) w trzecim punkcie pomiarowym wentylatora silników trakcyjnych (rys. 6) w funkcji przebiegu lokomotywy. Najlepszym modelem okazał się model liniowy, który bardzo dobrze opisuje zmiany poziomu drgań wentylatora $\mathrm{w}$ funkcji przebiegu. $\mathrm{W}$ oparciu o ten model przeprowadzono prognozę parametru do osiagnięcia wyznaczonej dla 
wzbudnicy wartości granicznej. Prognoza dla wentylatora silników trakcyjnych, podobnie jak dla wzbudnicy jest wiarygodna.

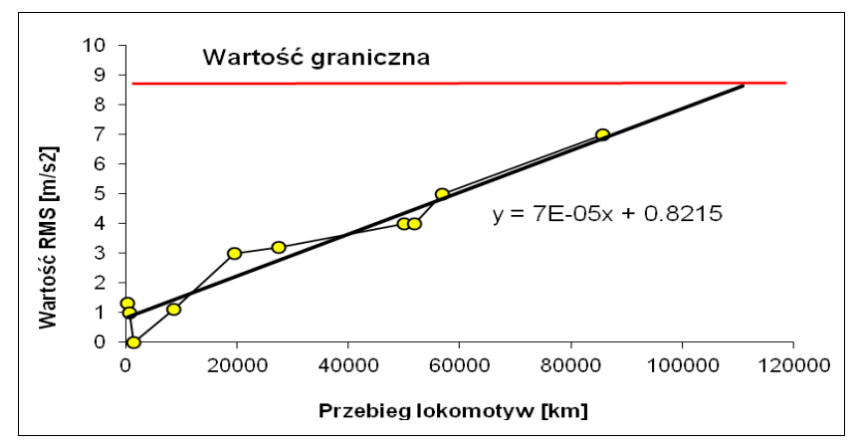

Rys. 11. Przebieg skutecznej wartości przyspieszenia drgań wentylatora silników trakcyjnych w punkcie pomiarowym $3 \mathrm{w}$ funkcji przebiegu lokomotywy

Przedstawione wyniki analiz, pokazują możliwości jakie daje nadzór drganiowy zespołów lokomotywy oraz prognoza dalszej poprawnej pracy (resursu) do osiągnięcia wartości granicznej przez obserwowany parametr diagnostyczny.

\section{Podsumowanie}

Głównym celem badań była analiza i ocena poziomu drgań podstawowych zespołów lokomotyw spalinowych serii SM42 w funkcji przebiegu. Badania zostały poparte normą drganiową PN - ISO $10816-1$. W pracy przeanalizowano pomiary poziomu drgań silnika spalinowego, prądnicy głównej, wzbudnicy, sprężarki powietrza oraz wentylatora silników trakcyjnych. Do analizy użyto wartości granicznej wyznaczonej metodą opracowaną przez C. Cempla, która polega na minimalizacji prawdopodobieństwa nie wykrycia awarii przy założonym poziomie zbędnych napraw.
Najlepszym parametrem do oceny stanu zespołów lokomotywy okazała się skuteczna wartość przyspieszeń drgań. Skuteczna wartość prędkości drgań posiadała niewielka dynamikę zmian w stosunku do skutecznej wartości przyspieszeń drgań.

Największy poziom drgań występuje na maszynach tłokowych, tj. silniku spalinowym i sprężarce powietrza oraz na prądnicy głównej, która jest bezpośrednio napędzana przez silnik spalinowy. Powyższe urządzenia już po niedużym przebiegu generują drgania na poziomie bliskim wartości granicznej. Natomiast najmniejszy poziom drgań występuje na urządzeniach elektrycznych, np. na wzbudnicy.

\section{Literatura}

[1] Bolewski ST., Kowalczyk E., Lokomotywy spalinowe serii SM42. Wydawnictwo Komunikacji i Łaczności, Warszawa 1971.

[2] Cempel C., Tomaszewski F., Diagnostyka maszyn. Zasady ogólne. Przykłady zastosowań. Międzynarodowe Centrum Naukowe Eksploatacji Majatku Trwatego. Radom 1992.

[3] Tomaszewski F.: Możliwości szacowania wartości granicznej symptomu diagnostycznego w zależności od bieżacego poziomu niezawodności obiektu. III Międzynarodowy Kongres Diagnostyki Technicznej, DIAGNOSTYKA'2004, Poznań, 6-9 września 2004, Diagnostyka, vol 30, tom 2, str. 137-140.

[4] Norma PN - ISO 10816 - 1, Ocena drgań maszyny na podstawie pomiarów na częściach niewirujacych. Styczeń 1998.

[5] www.transportszynowy.pl 